ҚАЗАҚСТАН РЕСПУБЛИКАСЫ

ҰЛТТЫҚ ҒЫЛЫМ АКАДЕМИЯСЫНЫН

АБАЙ АТЫНДАҒЫ ҚАЗАҚ ҰЛТТЫҚ

ПЕДАГОГИКАЛЫҚ УНИВЕРСИТЕТІНІҢ

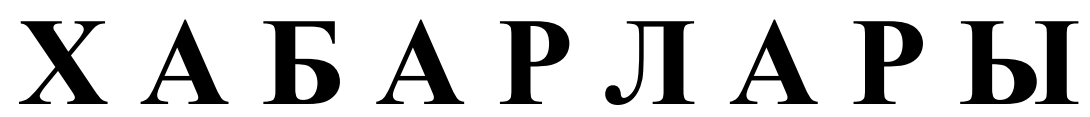

\section{ИЗВЕСТИЯ}

НАЦИОНАЛЬНОЙ АКАДЕМИИ НАУК РЕСПУБЛИКИ КАЗАХСТАН

КАЗАХСКИЙ НАЦИОНАЛЬНЫЙ

ПЕДАГОГИЧЕСКИЙ УНИВЕРСИТЕТ ИМ. АБАЯ

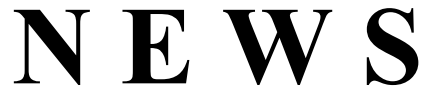

OF THE NATIONAL ACADEMY OF SCIENCES OF THE REPUBLIC OF KAZAKHSTAN

ABAY KAZAKH NATIONAL PEDAGOGICAL UNIVERSITY

ҚОҒАМДЫҚ ЖӘНЕ ГУМАНИТАРЛЫҚ ҒЫЛЫМДАР СЕРИЯСЫ

СЕРИЯ ОБЩЕСТВЕННЫХ И ГУМАНИТАРНЫХ НАУК

SERIES OF SOCIAL AND HUMAN SCIENCES

\author{
6 (322) \\ ҚАРАША - ЖЕЛТОҚСАН 2018 ж. \\ НОЯБРЬ - ДЕКАБРЬ 2018 Г. \\ NOVEMBER - DECEMBER 2018 \\ ИЗДАЕТСЯ С ЯНВАРЯ 1962 ГОДА \\ PUBLISHED SINCE JANUARY 1962 \\ ЖЫЛЫНА 6 РЕТ ШЫҒАДЫ \\ ВЫХОДИТ 6 РАЗ В ГОД \\ PUBLISHED 6 TIMES A YEAR
}

1962 ЖЫЛДЫҢ ҚАНТАР АЙЫНАН ШЫҒА БАСТАҒАН 
Ба с ре дактор

ҚР ҰҒА кұрметті мүшесі

Балықбаев Т.O.

Р е д а ц и я а лқ а сы:

экон. ғ. докторы, проф., ҚР ҰҒА академигі Баймұратов У.Б.; тарих ғ. докторы, проф., ҚР ҰҒА академигі Байпақов К.М.; филос. ғ.докторы, проф., ҚР ҰҒА академигі Есім Г.Е.; фил. ғ. докторы,, проф., ҚР ҰҒА академигі Қирабаев С.С.; эк. ғ. докторы, проф., ҚР ҰҒА академигі Кошанов А.К.; эк.ғ. докторы, проф., ҚР ҰҒА академигі Нәрібаев К.Н. (бас редактордың орынбасары); филос. ғ.докторы, проф., ҚР ҰҒА академигі Нысанбаев А.Н.; заң ғ. докторы, проф., ҚР ҰҒА академигі Сәбікенов С.Н.; заң ғ. докторы, проф., ҚР ҰҒА академигі Сүлейменов М.К.; эк. ғ. докторы, проф., ҚР ҰҒА академигі Сатыбалдин С.С.; тарих ғ. докторы, проф., ҚР ҰҒА академик Әбжанов Х.М.; тарих ғ. докторы, проф., ҚР ҰҒА корр. мүшесі Әбусеитова М.Х.; тарих ғ. докторы, проф., ҚР ҰҒА академик Байтанаев Б.А.; филол. ғ. докторы, проф., ҚР ҰҒА корр. мүшесі Жақып Б.А.; фил. ғ. докторы, проф., академик НАН РК Қалижанов У.К.; филол. ғ. докторы, проф., ҚР ҰҒА академик Қамзабекұлы Д.; тарих ғ. докторы, проф., ҚР ҰҒА академик Қожамжарова Д.П.; тарих ғ. докторы, проф., ҚР ҰҒА академик Койгелдиев М.К.; фил. ғ. докторы, проф., ҚР ҰҒА корр. мүшесі Кұрманбайұлы Ш.; тарих ғ. докторы, проф., ҚР ҰҒА корр. мүшесі Таймағанбетов Ж.К.; социол. ғ. докторы, проф., ҚР ҰҒА корр. мүшесі Шәукенова 3.К.; фил. ғ. докторы, проф., КР ҰҒА корр. мүшесі Дербісәлі А.; саяси. ғ. докторы, проф., Бижанов А.К., тарих ғ. докторы, проф., Кабульдинов 3.Е.; фил. ғ. докторы, проф., ҚР ҰҒА корр мүшесі Қажыбек Е.3.

\section{Р едакция ке н е с i:}

Молдова Республикасының ҰҒА академигі Белостечник Г. (Молдова); Әзірбайжан ҰҒА академигі Велиханлы Н. (Азербайджан); Тәжікстан ҰҒА академигі Назаров Т.Н. (Тәжікстан); Молдова Республикасының ҰҒА академигі Рошка А. (Молдова); Молдова Республикасының ҰҒА академигі Руснак Г. (Молдова); Әзірбайжан ҰҒА корр. мүшесі Мурадов Ш. (Әзірбайжан); Әзірбайжан ҰҒА корр. мүшесі Сафарова 3. (Әзірбайжан); э. ғ. д., проф. Василенко В.Н. (Украина); заң ғ. докт., проф. Устименко В.А. (Украина)

«Қазақстан Республикасы Ұлттық ғылым академиясының Хабарлары. Қоғамдық және гуманитарлық ғылымдар сериясы». ISSN 2224-5294

Меншіктенуші: «Қазақстан Республикасының Ұлттық ғылым академиясы» РҚБ (Алматы қ.)

Қазақстан республикасының Мәдениет пен ақпарат министрлігінің Ақпарат және мұрағат комитетінде 30.04.2010 ж. берілген № 10894-Ж мерзімдік басылым тіркеуіне қойылу туралы куәлік

Мерзімділігі: жылына 6 рет.

Тиражы: 500 дана.

Редакцияның мекенжайы: 050010, Алматы қ., Шевченко көш., 28, 219 бөл., 220, тел.: 272-13-19, 272-13-18, http://nauka-nanrk.kz. social-human.kz

(C) Қазақстан Республикасының Ұлттық ғылым академиясы, 2018

Типографияның мекенжайы: «Аруна» ЖК, Алматы қ., Муратбаева көш., 75. 
Главный редактор

Почетный член НАН РК

T.O. Балыкбаев

Р е дак ци онн а я коллег и я:

докт. экон. Н., проф., академик НАН РК У.Б. Баймуратов; докт. ист. н., проф., академик НАН РК К.М. Байпаков; докт. филос. Н., проф., академик НАН РК Г.Е. Есим; докт. фил. Н., проф., академик НАН РК С.С. Кирабаев; докт. экон. Н., проф., академик НАН РК А.К. Кошанов; докт. экон. Н., проф., академик НАН РК К.Н. Нарибаев (заместитель главного редактора); докт. филос. н., проф., академик НАН РК А.Н. Нысанбаев; докт. юр. Н., проф., академик НАН РК С.Н. Сабикенов; докт. юр. н., проф., академик НАН РК М.К. Сулейменов; докт. экон. Н., проф., академик НАН РК С.С. Сатубалдин; докт. ист. н., проф., академик НАН РК Х.М. Абжанов; докт. ист. н., проф., чл.-корр. НАН РК М.Х. Абусеитова; докт. ист. н., проф., академик НАН РК Б.А. Байтанаев; докт. фил. н., проф., чл.-корр. НАН РК Б.А. Жакып; докт. фиолол. н., проф., академик НАН РК У.К. Калижанов; докт. фил. н., проф., академик НАН РК Д. Камзабекулы; докт. ист. н., проф., академик НАН РК Д.П. Кожамжарова; докт. ист. н., проф., академик НАН РК М.К. Койгельдиев; докт. филол. н., проф., чл.-корр. НАН РК Ш. Курманбайулы; докт. ист. н., проф., чл.корр. НАН РК Ж.К. Таймаганбетов; докт. социол. н., проф., чл.-корр. НАН РК З.К. Шаукенова; д. филол. н., проф., чл.-корр. НАН РК А. Дербисали; доктор политических наук, проф., Бижанов А.К.; доктор ист. наук, проф., Кабульдинов 3.Е.; доктор филол. н., проф., член-корр. НАН РК Қажыбек Е.3.

Р е дак ци онны й с ов ет

академик НАН Республики Молдова Г. Белостечник (Молдова); академик НАН Азербайджанской Республики Н. Велиханлы (Азербайджан); академик НАН Республики Таджикистан Т.Н. Назаров (Таджикистан); академик НАН Республики Молдова А. Рошка (Молдова); академик НАН Республики Молдова Г. Руснак (Молдова); чл.-корр. НАН Азербайджанской Республики Ш. Мурадов (Азербайджан), член-корр. НАН Азербайджанской Республики 3.Сафарова (Азербайджан); д. э. н., проф. В.Н. Василенко (Украина); д.ю.н., проф. В.А. Устименко (Украина)

Известия Национальной академии наук Республики Казахстан. Серия общественных и гуманитарных наук. ISSN 2224-5294

Собственник: РОО «Национальная академия наук Республики Казахстан» (г. Алматы)

Свидетельство о постановке на учет периодического печатного издания в Комитете информации и архивов

Министерства культуры и информации Республики Казахстан № 10894-Ж, выданное 30.04.2010 г.

Периодичность 6 раз в год

Тираж: 500 экземпляров

Адрес редакции: 050010, г. Алматы, ул. Шевченко, 28, ком. 219, 220, тел. 272-13-19, 272-13-18, www:nauka-nanrk.kz / social-human.kz

(C) Национальная академия наук Республики Казахстан, 2018 г.

Адрес типографии: ИП «Аруна», г. Алматы, ул. Муратбаева, 75

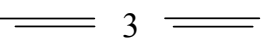


Chief Editor

\section{Honorary member of NAS RK \\ Balykbayev T.O}

Editorial board:

Doctor of economics, prof, academician of NAS RK Baimuratov U.B.; doctor of history, prof, academician of NAS RK Baipakov K.M.; doctor of philosophy, prof, academician of NAS RK Esim G.E.; doctor of philology, prof, academician of NAS RK Kirabayev S.S.; doctor of economics, prof, academician of NAS RK Koshanov A.K.; doctor of economics, prof, academician of NAS RK Naribayev K.N. (deputy editor-in-chief); doctor of philosophy, prof, academician of NAS RK Nyssanbayev A.N.; doctor of law, prof, academician of NAS RK Sabikenov S.N.; doctor of law, prof, academician of NAS RK Suleymenov M.K.; doctor of economy, prof, academician of NAS RK Satybaldin S.S.; doctor of history, prof, academician of NAS RK Abzhanov H.M; doctor of history, prof, corresponding member of NAS RK Abuseitova M.H.; doctor of history, prof, academician of NAS RK Baitanaev B.A.; doctor of philology, prof, corresponding member of NAS RK Zhakyp B.A.; doctor of philology, prof, academician of NAS RK Kalizhanov U.K.; doctor of philology, prof, academician of NAS RK Hamzabekuly D.; doctor of history, prof, academician of NAS RK Kozhamzharova D.P.; doctor of history, prof, academician of NAS RK Koigeldiev M.K.; doctor of philology, prof, corresponding member of NAS RK Kurmanbaiuly Sh.; doctor of history, prof, academician of NAS RK Taimaganbetov J.K.; doctor of sociology, prof, corresponding member of NAS RK Shaukenova Z.K.; doctor of philology, prof, corresponding member of NAS RK Derbisali A.; doctor of political science, prof Bizhanov A.K; doctor of History, prof Kabuldinov Z.E.; doctor of philology, prof, corresponding member of NAS RK Kazhybek E.Z.

\section{Editorial staff:}

Academician NAS Republic of Moldova Belostechnik.G (Moldova); Academician NAS Republic of Azerbaijan Velikhanli N. (Azerbaijan); Academician NAS Republic of Tajikistan Nazarov T.N. (Tajikistan); Academician NAS Republic of Moldova Roshka A. (Moldova) Academician NAS Republic of Moldova Rusnak G. (Moldova); Corresponding member of the NAS Republic of Azerbaijan Muradov Sh. (Azerbaijan); Corresponding member of the NAS Republic of Azerbaijan Safarova Z. (Azerbaijan); Associate professor of Economics Vasilenko V.N. (Ukraine), Associate professor of Law Ustimenko V.A. (Ukraine)

News of the National Academy of Sciences of the Republic of Kazakhstan. Series of Social and Humanities. ISSN 2224-5294

Owner: RPA "National Academy of Sciences of the Republic of Kazakhstan" (Almaty)

The certificate of registration of a periodic printed publication in the Committee of information and archives of the Ministry of culture and information of the Republic of Kazakhstan N 10894-Ж, issued 30.04.2010

Periodicity: 6 times a year

Circulation: 500 copies

Editorial address: 28, Shevchenko str., of. 219, 220, Almaty, 050010, tel. 272-13-19, 272-13-18, www:nauka-nanrk.kz / social-human.kz

(C) National Academy of Sciences of the Republic of Kazakhstan, 2018

Address of printing house: ST "Aruna", 75, Muratbayev str, Almaty 
N E W S

OF THE NATIONAL ACADEMY OF SCIENCES OF THE REPUBLIC OF KAZAKHSTAN

SERIES OF SOCIAL AND HUMAN SCIENCES

ISSN 2224-5294

https://doi.org/10.32014/2018.2224-5294.52

Volume 6, Number 322 (2018), 185 - 194

UDC 336.225

\author{
G.Kerimbek $^{1}$, L.Moldashbayeva ${ }^{1}$, K.Jrauova ${ }^{2}$, A. Azhmukhamedova ${ }^{1}$, A.Misanova ${ }^{1}$ \\ ${ }^{1}$ L.N.Gumilyov Eurasian National University Astana; \\ ${ }^{2}$ Korkyt Ata Kyzylorda State University, Kyzylorda \\ kerimbek2009@mail.ru, moldashbayeva_1p@enu.kz,75zhkyra@mail.ru, \\ azhmuxamedova@mail.ru, mizanova707@mail.ru
}

\title{
ANALYSIS AND EVALUATION OF REDUCTION OF TAX RECOVERY OF THE REPUBLIC OF KAZAKHSTAN ON THE BUDGET OF THE REPUBLIC OF KAZAKHSTAN
}

\begin{abstract}
The direction of «Taxation of tax administration» consists of four initiatives: electronic invoices and information labeling systems, increased tax collection through the administration of VAT by using blockechnology, as well as consolidating the database of different sources. The «Electronic invoices» information platform has been recently created to add functionality related to controlling the convenience of the interface and the movement of goods. «The number of users of the system is increasing day by day, and today it has more than 158 thousand, with more than 65 million ISFs». The information labeling system «Goods Marking» provides for the labeling of products made of leather and the EAEU framework. Finally, as a result of digitization of the taxation system, it is planned to collect GDP by approximately $9 \%$ by 2025 without increasing the tax burden and size.
\end{abstract}

Keywords: taxes, budget, investments, income, expenses, tax administration, customs, electronic invoice.

The state budget is the central link of the financial system of the Republic of Kazakhstan, as in any other country. The budget is an essential part of the state and an essential part of its sovereignty. The republican budget is the centralized financial resources of the state to finance accumulated funds and sources of tax and other sources of income and to finance the republican important programs and activities [1-2].

In recent years, the republic has been focusing on regional economics, regional development, namely, the economic growth, social status, financial position of the population, welfare of the population, attraction of domestic and foreign investments and its effective utilization, industry, agriculture, as well as the development of small and medium-sized businesses, the special attention is paid to the solution of such issues. The place where the tax system is a special place. About $70 \%$ of state budget revenues are tax revenues [3-5].

The system of tax system of the Republic of Kazakhstan is assigned to the President, the Parliament, the Government and the Ministry of Finance under the Constitution of the Republic of Kazakhstan.

The budget system of the Republic of Kazakhstan includes budgets of different levels oriented at economic relations and corresponding legal norms. The republican and local budgets forming the state budget, depending on the different levels of the budget, are envisaged [6-9].

The republican budget is a part of the budgetary system, the basic level of the state budgetary system, the centralized management apparatus. It is an important economic sector that provides funding for all measures of economic, social and credit development in general [10-13].

Incomes of the republican budget in 2016 will amount to $7662,2 \mathrm{bln}$. and in $2017-9691.8$ billion tenge. The growth rate is $126.5 \%$. Including tax receipts: $2016-4275.9$ billion tenge. tenge, in $2017-$ 4848.0 billion tenge, growth rate $-113.4 \%$. Non-tax revenues: 298.2 billion tenge in $2016,159.9$ billion tenge in 2017, growth rate -53.6 , see Table 1 . 
Table 1 - Revenues of the republican budget, bln. tenge

\begin{tabular}{|c|c|c|c|c|c|c|c|}
\hline Title & 2016 & $\%$ share & $\begin{array}{l}\text { To GDP } \\
\text { by } \%\end{array}$ & 2017 & $\%$ share & $\begin{array}{c}\text { To } \\
\text { GDP } \\
\text { by } \%\end{array}$ & $\begin{array}{l}\text { Growth } \\
\text { Rate } \%\end{array}$ \\
\hline Revenues all & 7662,2 & 100,0 & 16,3 & 9691,8 & 100,0 & 18,5 & 126,5 \\
\hline Income & 4581,9 & 50,8 & 9,8 & 5012,3 & 51,7 & 9,6 & 109,4 \\
\hline Tax receipts, including: & 4275,9 & 93,3 & 9,1 & 4848,0 & 96,7 & 9,3 & 113,4 \\
\hline Corporate income tax & 1437,4 & 33,6 & 3,1 & 1538,8 & 31,7 & 2,9 & 107,1 \\
\hline VAT on goods of domestic manufacture & 634,9 & 14,8 & 1,4 & 646,8 & 13,3 & 1,2 & 101,9 \\
\hline VAT on imported goods & 860,8 & 20,1 & 1,8 & 1017,9 & 21,0 & 1,9 & 118,2 \\
\hline Production of mineral resources & 159,3 & 3,7 & 0,3 & 259,2 & 5,3 & 0,5 & 162,7 \\
\hline Tax imposed & 242,9 & 5,7 & 0,5 & 269,6 & 5,6 & 0,5 & 111,0 \\
\hline Import customs duties & 639,0 & 14,9 & 1,4 & 854,5 & 17,6 & 1,6 & 133,7 \\
\hline RES to crude oil & 298,2 & 6,5 & 0,6 & 159,9 & 3,2 & 0,3 & 53,6 \\
\hline Non-tax receipts & 7,8 & 0,2 & & 4,3 & 0,1 & & 55,8 \\
\hline Receipts from sale of fixed capital & 3080,3 & 40,2 & 6,6 & 4679,5 & 48,3 & 8,9 & 151,9 \\
\hline Transfers, including: & 2110,0 & 68,5 & 4,5 & 2880,0 & 61,5 & 5,5 & 136,5 \\
\hline Guaranteed Transfer from NF & 745,6 & 24,2 & 1,6 & 1534,3 & 32,8 & 2,9 & 205,8 \\
\hline Target transfer from NC & 224,7 & 7,3 & 0,5 & 265,2 & 5,7 & 0,5 & 118,0 \\
\hline $\begin{array}{llll}\begin{array}{l}\text { Transfers } \\
\text { agencies }\end{array} & \text { from lower } & \text { government } \\
\end{array}$ & 46971,2 & & & 52394,5 & & & \\
\hline
\end{tabular}

At the same time, $96.7 \%$ of tax revenues on net income of the republican budget, and $3.2 \%$ nontax (Figure 1).

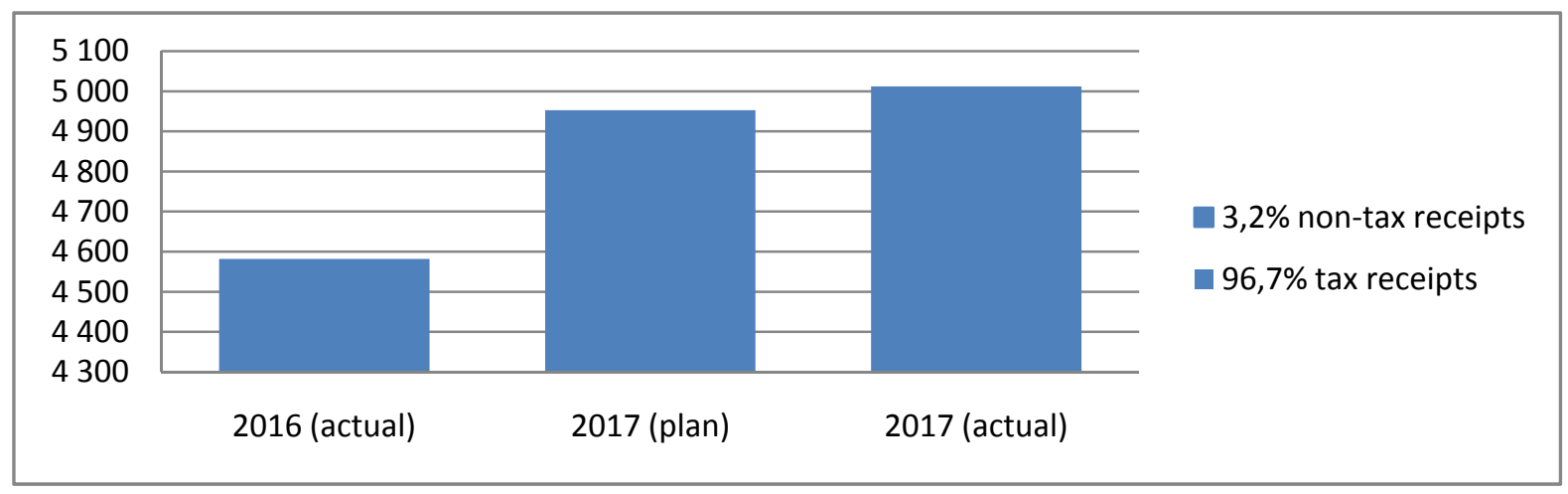

Figure 1 - Revenues from net income of the republican budget

Note - from the source of the Ministry of Finance of the Republic of Kazakhstan

Net revenues of the national budget in 2017 were fulfilled at 59 billion tenge, or 101.2\%, as shown in Figure 2. 


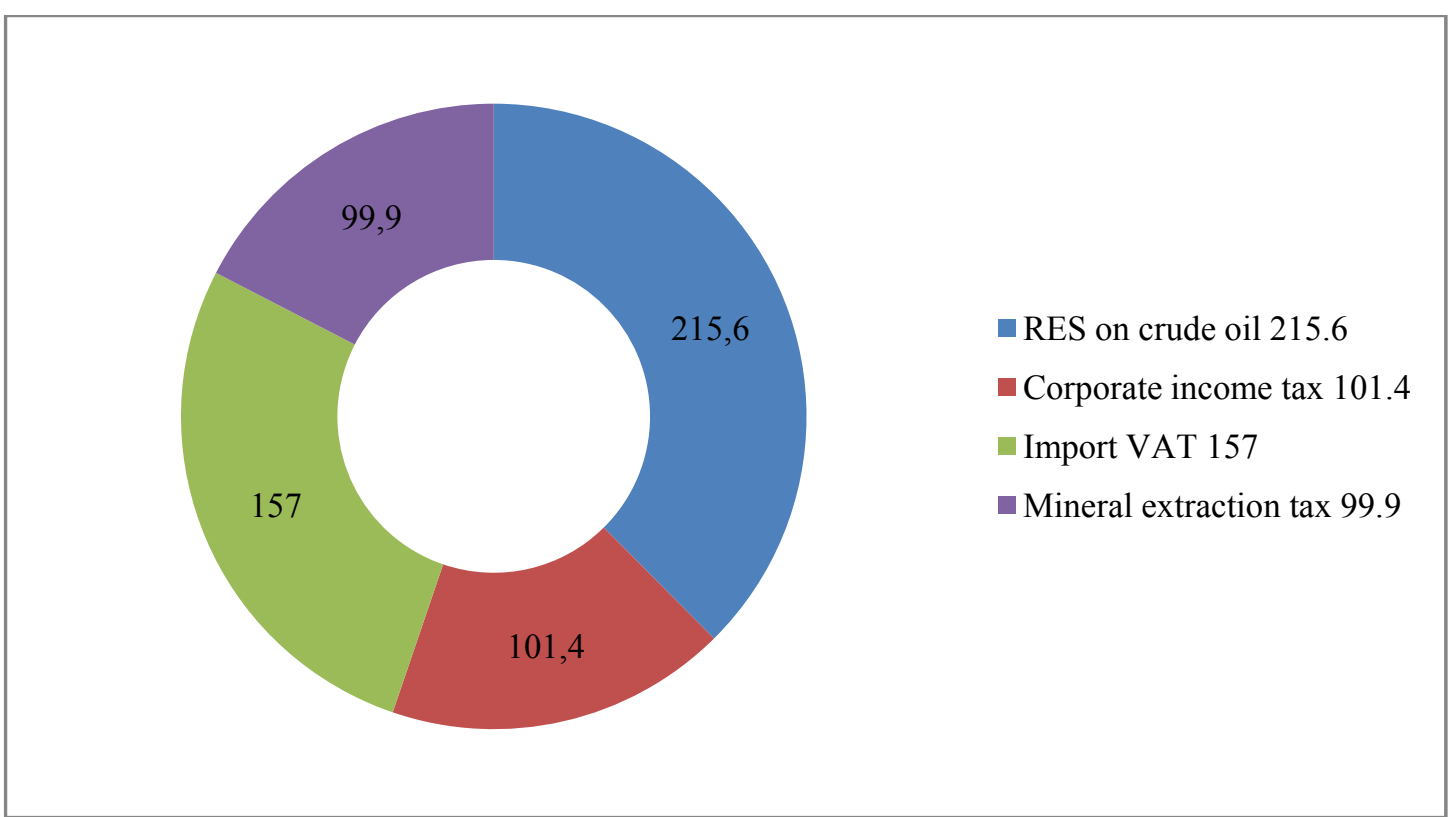

Figure 2 - Revenues from net income of the national budget

Note - from the source of the Ministry of Finance of the Republic of Kazakhstan

Growth factors:

- rise in metal prices;

- increase in the rate and the cost of the RES on crude oil (assumed to be 50 US dollars, almost $\$ 52.4$ in 2017);

- increase of imports and change of tenge exchange rate to Russian rubles;

- improvement of administration;

- one-off receipts (from Corporation «Kazakhmys» LLP).

The larger the specific weight of the herd:

$-35.6 \%$ - corporate income tax;

- 38.4\% - receives value-added tax (Figure 3).

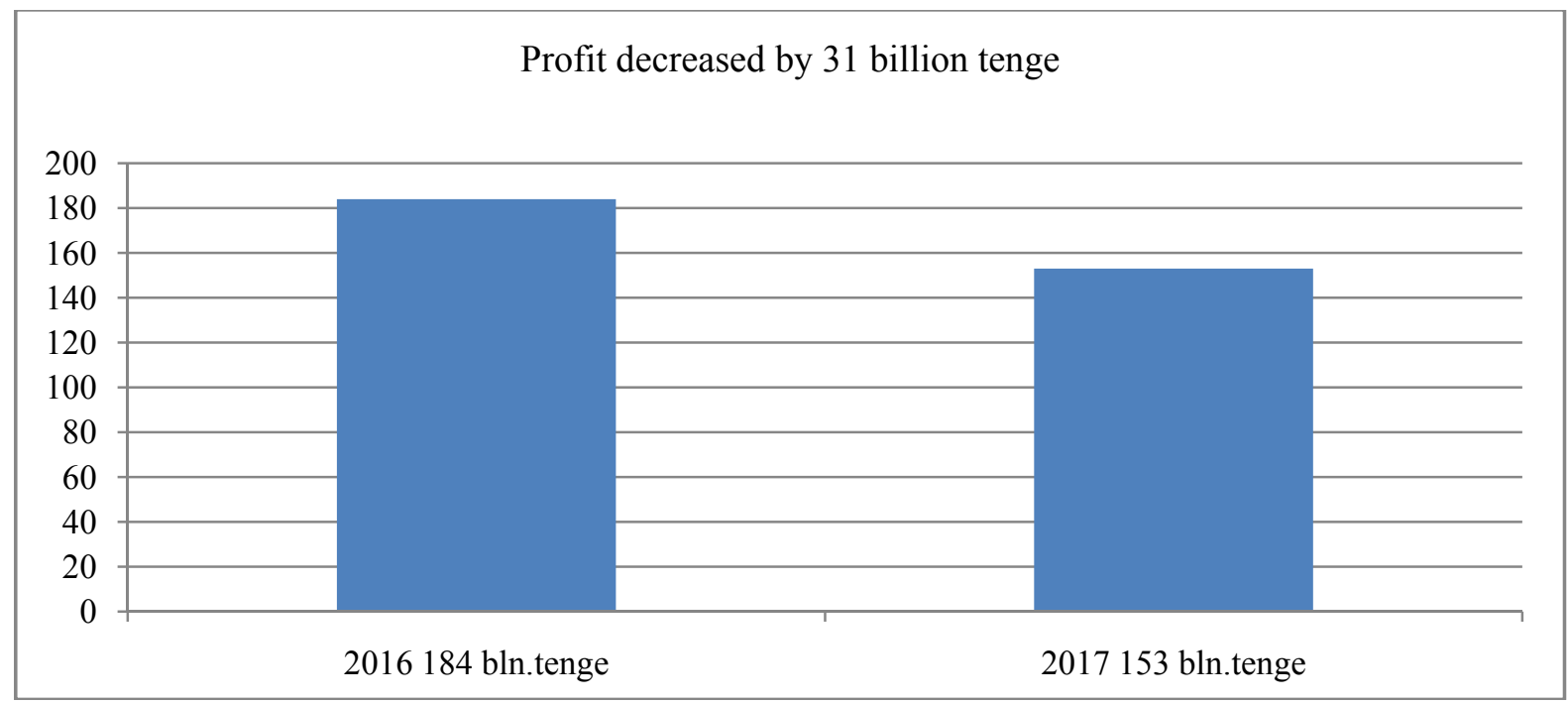

Figure 3 - Contributions to the national budget

Note - from the source of the Ministry of Finance of the Republic of Kazakhstan 
The distribution by category is shown in Figure 4 .

\section{In the category of categories}

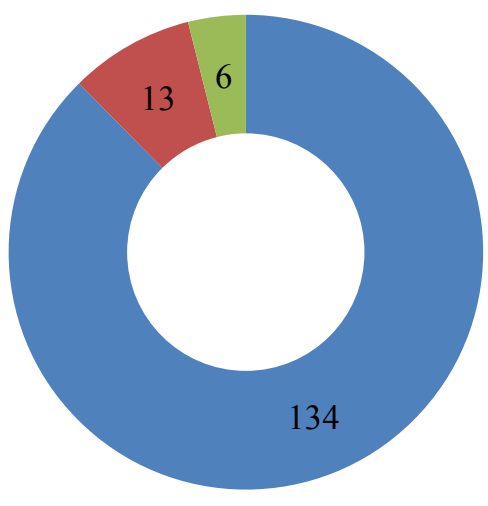

- Legal entities

- Individuals

- Individual entrepreneurs

Figure 4 - Classification of funds by categories to the national budget

Note - from the source of the Ministry of Finance of the Republic of Kazakhstan

In the category of above categories we see the indicators of legal entities and individuals and individual entrepreneurs.

Decreased by:

- cash withdrawal;

- recognizing debtor bankrupt;

- submission of additional tax returns;

- other reasons (minimized by verification report, complaint reports, etc.).

The parameters of the national budget for 2017 are presented in Table 2.

Table 2 - Parameters of the republican budget for 2017

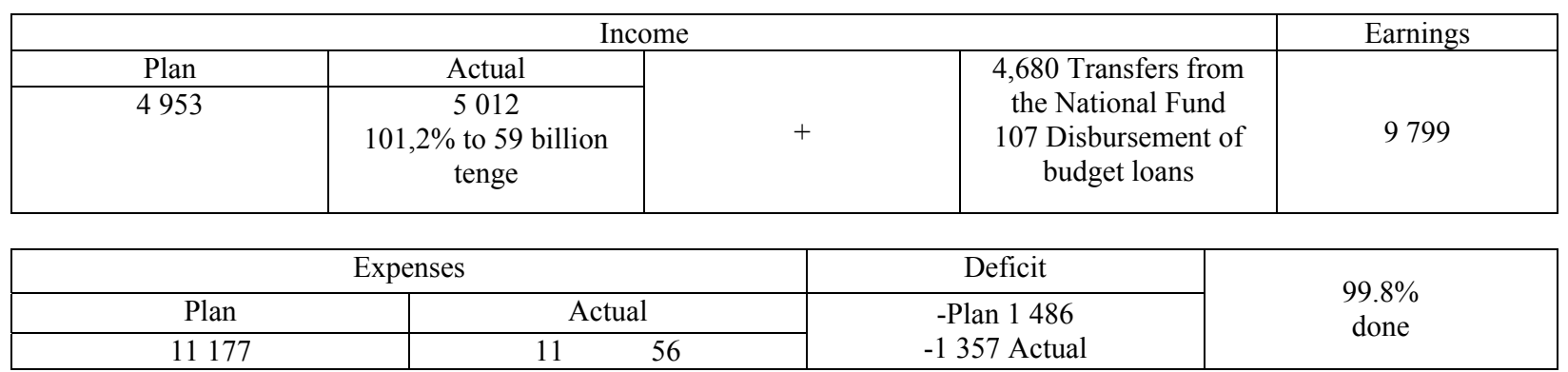

Parameters of the republican budget in 2017 are planned and actual indicators of income and expenditure.

Economic Development:

- Nurly zhol - 696 billion tenge. The volume of transit cargo within the territory of Kazakhstan is $18.1 \mathrm{mln}$. tons (Table 16.9). The second track in Almaty 1 - Shu was introduced, the capacity of the site was increased from 17 pairs of freight trains to 68 pairs per day, freight trains increased by 1.5 times (from $27.8 \mathrm{~km} / \mathrm{s}$ to $40 \mathrm{~km} / \mathrm{h}$ ), Almaty and the number of freight traffic between Shu stations decreased by 3.5 hours. 05.6 thousand jobs were created (in the plan -75.3 thousand), including 14.4 thousand permanent jobs. 
- Development of agro-industrial complex - 386 billion tenge. In the amount of 231.8 billion Tenge, 197 applications of subjects of agrarian and industrial complex were subsidized, 7532 of the Investors' Agenda 21 priority. 1816 subjects of AIC (1500 in the plan) were financed for spring sowing and harvesting, $3 \mathrm{mln}$. ha was covered.

- Development of regions - 248 billion tenge. Heat supply - $314.8 \mathrm{~km}$, power supply $-6493.2 \mathrm{~km}$, gas supply $-2086.2 \mathrm{~km} .93 .8 \%$ of the urban population has access to centralized water supply $57.4 \%$ of the rural population.

Entrepreneurship Support:

Business Road Map 2020 - 47 billion tenge:

- 2287 projects worth 36.1 billion tenge subsidized;

- 1064 projects worth 15 billion tenge were guaranteed;

- Grant was awarded to 276 projects for 490.3 million tenge;

- 772 microcredit were issued for KZT 4.3 billion;

- 113,393 clients received 237,8 thousand consultations and services.

Effective employment -79 billion tenge

- 7227 micro credits. 4,123 individuals have already started their business

Employment centers employed 315.5 thousand people

Improving people's livelihoods

Nurly zhol -171 billion tenge. 341.7 thousand square meters. rental and commercial housing was put into operation. For socially vulnerable groups of the population 288 thousand square meters without the right to purchase. (5376 apartments) was started.

Education development - 444 billion tenge. $90.5 \%$ of children aged 3-6 are enrolled in up-to-date education ( $87.5 \%$ of the plan). $86.7 \%$ of graduates of state educational institutions were employed in the first year after their graduation.

Health -176 billion tenge:

Early detection of new malignant neoplasms (stage 1-2) was 59.2\% (plan 58.2\%);

- In the regions additional 10 stroke centers were opened.

The implementation of budget programs is shown in Figure 5.
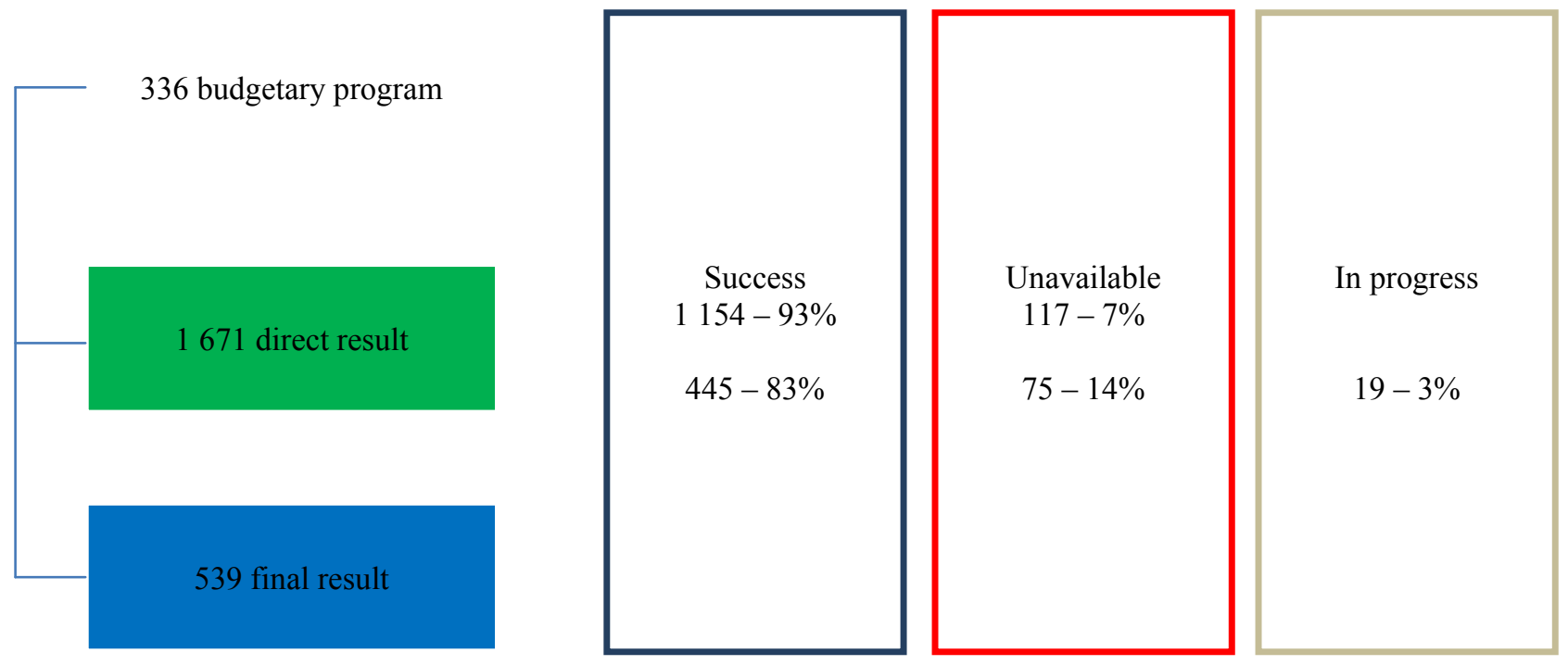

Figure 5 - Measures to implement budget programs

Note - from the source of the Ministry of Finance of the Republic of Kazakhstan

It is estimated that 21.1 billion tenge, ie $0.2 \%$ of the total expenditure, can be found in Table 3 . 
Table 3 - The results of implementation of budget programs

\begin{tabular}{|l|l|l|l|}
\hline & 2016 & 2017 & change \\
\hline Execution & 8501 & 11156 & +1.3 times \\
\hline Eliminate & 34,3 & 2,6 & -13 times \\
\hline Retained earnings & 75,6 & 3,4 & -22 times \\
\hline Not worked & 36 & 15 & -2.4 times \\
\hline \multicolumn{2}{|l|}{ Note - from the source of the Ministry of Finance of the Republic of Kazakhstan } \\
\hline
\end{tabular}

The greatest disintegration was formed by:

- 4.1 - Ministry of Health;

- 3,2 - Ministry of Education and Science;

- 1,7 - Ministry of Agriculture

- 1,7 - Ministry of Defense;

- 1,4 - State Security Committee

High performance of the republican budget expenditures

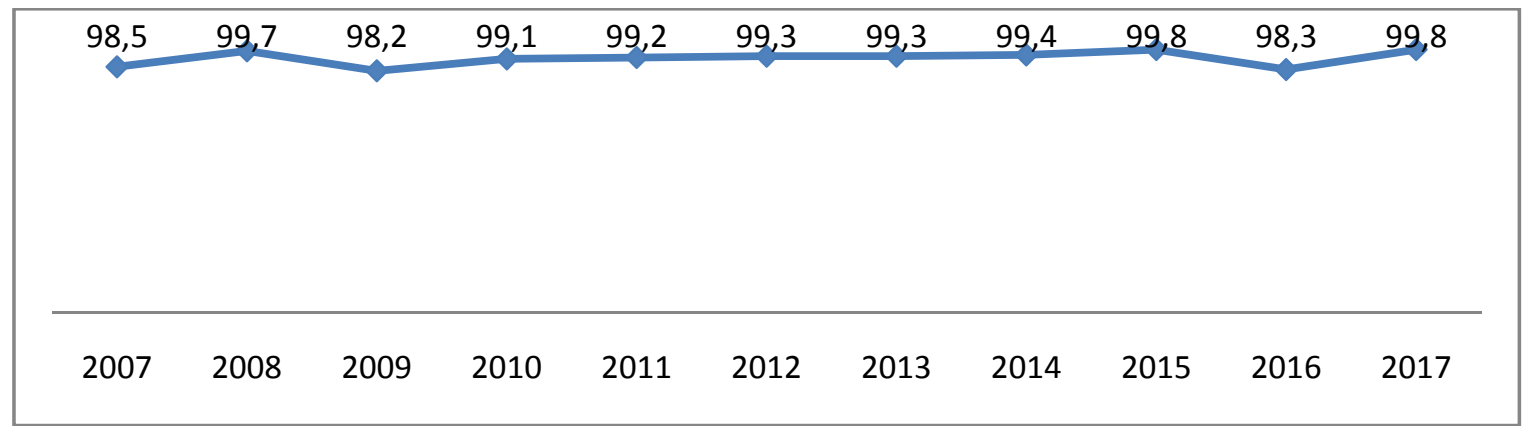

Improper performance is 508 billion dollars. Tenge

Failure to implement budget programs for 89 billion tenge:

- unsuccessful - 15 billion tenge;

- return of unreasonably low paid IT and budget credits - 1,7 billion tenge;

- return of non-utilized NT in 2016 - 20.6 billion tenge;

- return of unused budget credits allocated from the RB - 7.1 billion tenge;

- the balance of unused profits in the CPS RK - 45 billion tenge.

413 billion On the audit control materials:

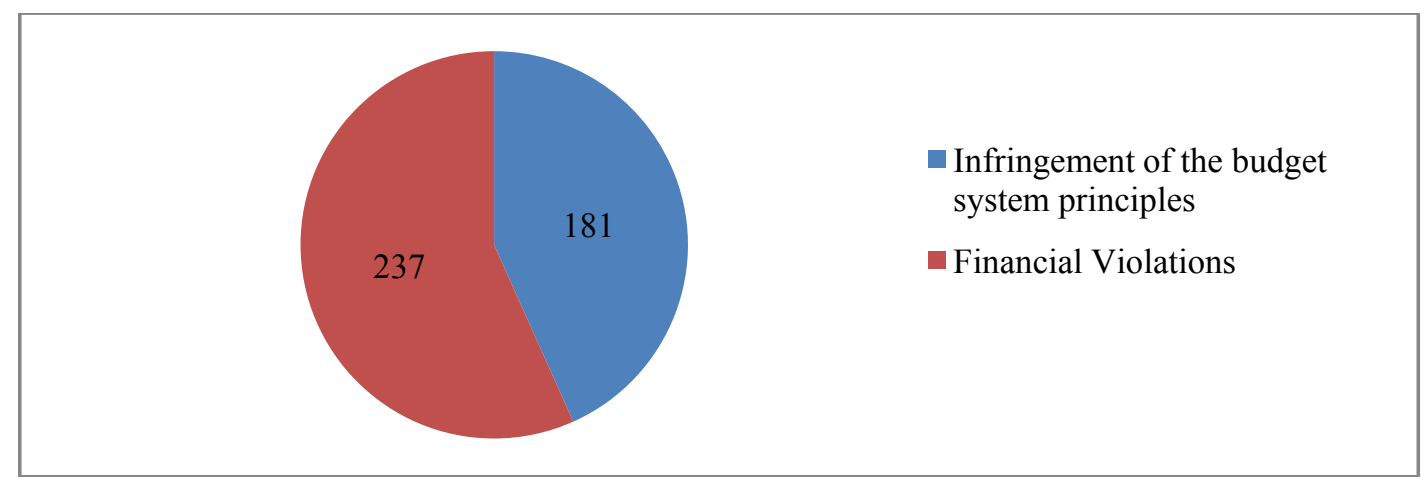

* billion tenge

Indicators of violations in the budget system. By 2017, all violations were damaged in the total amount of 418 billion tenge.

We know that land is the property of individuals and legal entities as the main source of income for private entrepreneurship. So today, the size of land and property tax paid by individuals and legal entities 
does not meet the requirements of market economy. The main disadvantage here is the market value of land value in globalization and its role is ignored:

- improvement of tax and customs administration;

- increased revenue collection project. The share of revenues of the consolidated budget in GDP in 2017 will be $16.8 \%$ (15.8\%), the republican budget $-9.3 \%$;

- the checks are reduced by $45 \%$. To accelerate the management of the taxpayer's voluntary commitment;

- tax collection has increased. In 2017 reached 123 billion dollars. or 34\% more than in 2016.

In the plan:

- customs and customs administration within the Digital Kazakhstan program will increase from $15.2 \%$ of GDP in 2016 to $25 \%$ by 2025 . The share of revenues in GDP in 2018 is $17 \%$;

- launch of «Astana-1» will reduce the time from 18 times to import (from 1.5 to 5 minutes);

- use of block technologies in the administration of indirect taxes;

- by the end of 2019 a cycle will be added to added value control: from the boundary (manufacturer) to the end user.

11156 were directed to:
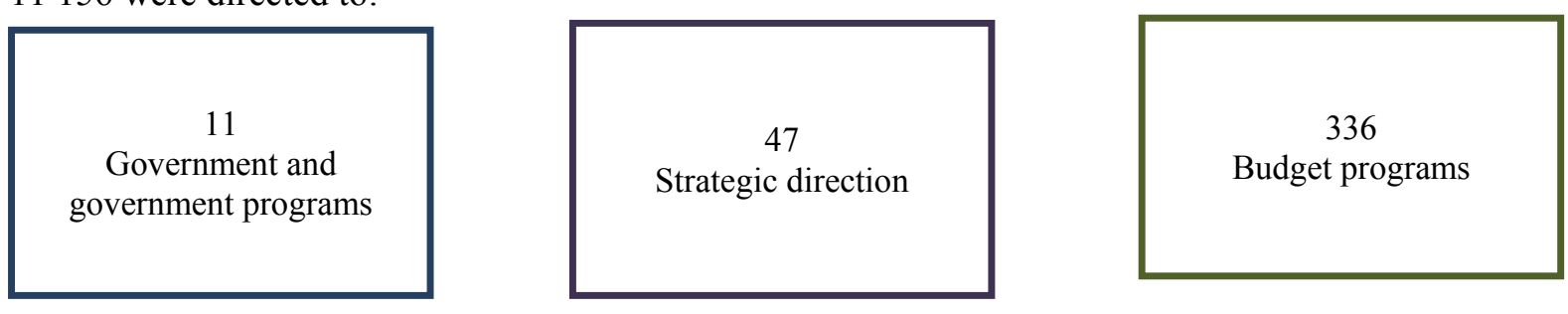

Implementation of strategic directions
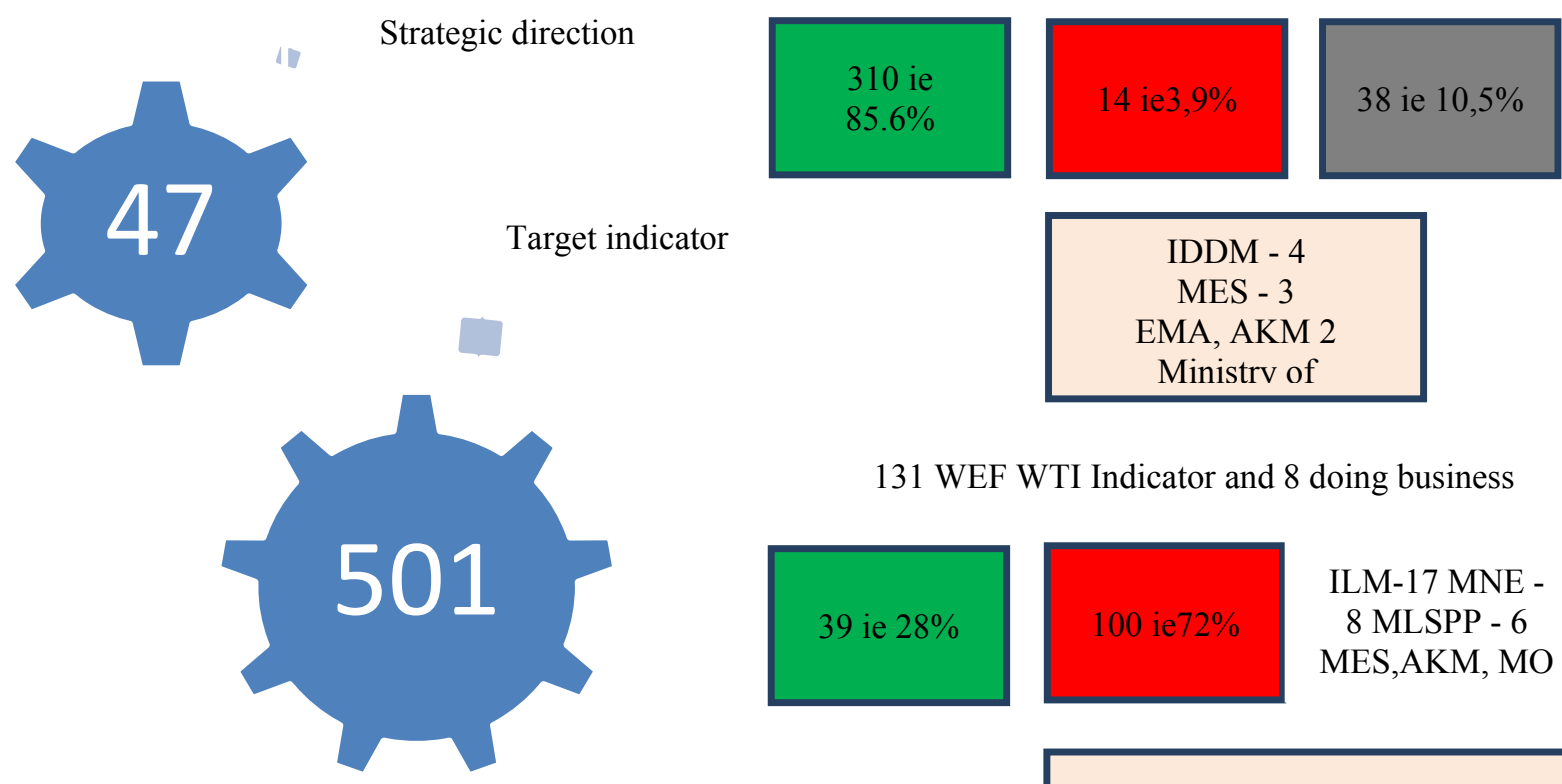

arget indicator

IDDM - 4

MES - 3

EMA, AKM 2

Ministrv of

131 WEF WTI Indicator and 8 doing business
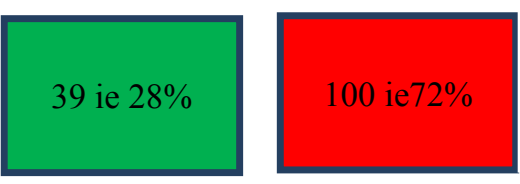

ILM-17 MNE -

8 MLSPP - 6

MES,AKM, MO

47 are common to all RWEs

14 target indicators are not available

IDM-4:

- Growth of investment in fixed assets in the processing industry made $104.7 \%$ (plan 105.3\%) due to decrease in capital investments; 
- $65.9 \%$ of regional and district roads are good and satisfactory due to previous spring floods (66\% plan);

- the rolling stock due to overhaul of OJSC «KTZh»: freight $-46.8 \%$ (43\% discount), passenger $45.9 \%$.

MES-3:

$-0.6 \%$ of the school is emergency (plan $0 \%$ );

$-0.8 \%$ of the schools were shifted in three shifts (plan $\%$ );

- No PPP project on PPP project «Life Center of Testing and Pedagogical Qualifications».

DMM-2:

- maternal mortality - $12 \%$ per 100,000 live births (plan $11.4 \%$ ) causes obstetric complications;

- resident or Passport Health (Plan 2\%), for example, the project WB does not correspond to the graphics procurement platform.

AKM-2:

$-81.8 \%$ of the population is covered by coded tele-radio broadcasting ( $87 \%$ of the plan) due to the prolonged and complexity of tender procedures (failure of contractor LLP «UshSat» to comply with the contractual terms of RTS infrastructure construction);

- the State Commission for Citizens provides $65 \%$ of services in electronic format (no less than $66 \%$ ), measures have been taken to organize the interaction of IP in order to prevent citizens' electronic inquiries within the framework of the RK tasks, which contributed to the reduction.

MLSPP - 1:

- among those applying for employment centers, $62.8 \%$ of employed people were employed (75\% of the plan), which is due to revision of employment indicators for unemployed and self-employed.

Measures to ensure the effectiveness of budget expenditures:

- waste minimization mechanisms have been developed in the legal framework of the CPS Waste - to return waste to budget revenues or to allow them to be used in other quasi-public sector projects;

- the external borrowing mechanism of the quasi-public sector entities has been settled legally - by agreeing with the Government;

- procedures for planning PPP projects and control over contingent liabilities of the state were simplified - 133 contracts worth 90.4 billion tenge were registered in the $\mathrm{CU}$;

- reduction of accounts receivable - long-term investment. payment of advance only after full repayment of previously paid amounts on projects.

Planning:

- introduction of a single system of public procurement on the principle of centralized service in the new law on public procurement, transfer of all quasi-public procurement to electronic format;

- introduction of professional certification system of public accountants. to start from the beginning.

It is necessary to revise the periodicity of budget formation, to consider draft strategic plans before the formation of limits and to reduce the situation with adjustments to strategic plans [14-17].

The Ministry of Finance is actively digitizing tax and customs procedures, and is simplifying business operations. Minister of Finance Bakhyt Sultanov said at the Government meeting that «a new strategic model on the basis of the digitalization project» is to form a successful budget base on the platform of interaction between the state and business, without interfering in the functioning of honest business. «During the transition to the improvement of customs administration and electronic customs declaration, the work will be carried out in two ways, ie the e-window on export-import operations will be created on the basis of the ASTANA information system. Information system «ASTANA-1» is a multifunctional and complex system that allows for the creation of favorable conditions for the participants of the FEA and allows automated implementation of control before the release of goods from the moment of preliminary notification of all customs clearance». Information system «ASTANA-1» will be launched in step-by-step mode. Since October 1, 2017, there is a subsidized «Customs transit» system. The main difference of the new system from the existing system is the ability to reduce the number of information systems, to declare paperless production of goods, vehicles and cars. Starting from January 1, 2018, the rest of the ASTANA1 IS has been commissioned. From January 1, 2018, a mechanism to operate on nine permissive documents has been launched within one window. Also, in 2018, the state database «E-Licensing» will be 
submitted electronically with the information on 42 permits issued by the state bodies through the integration of the ASTANA-1 information system.

The direction of «Taxation of tax administration» consists of four initiatives: electronic invoices and information labeling systems, increased tax collection through the administration of VAT by using blockechnology, as well as consolidating the database of different sources. The «Electronic invoices» information platform has been recently created to add functionality related to controlling the convenience of the interface and the movement of goods. «The number of users of the system is increasing day by day, and today it has more than 158 thousand, with more than 65 million ISFs». The information labeling system «Goods Marking» provides for the labeling of products made of leather and the EAEU framework.

On November 27 this project was launched in our country. The Minister said that about 20 companies were added to the system within three days and 60 product labels had been completed. «Next year, the list of goods will be expanded according to the results of this project. It should be noted that we are implementing this initiative in close cooperation with our partners in the Eurasian Economic Union. Implementation of these initiatives will be a barrier to non-commodity transactions accompanied by a copy of false documents». According to the Ministry, VAT administration through blockechnology will facilitate the creation of a personalized database that will allow the taxpayers to monitor the financial transaction chain immediately and implement the guarantees for VAT refund.

The tax administration of the European Union states that it is considering introducing block technology. In Kazakhstan, the integration of block technology (IBM Hyperledger Fabric) and the Intelligent Intelligence (IBM Watson) with the integration of the Ministry of Finance and the ITP Autonomous Cluster Fund was launched. «The blockage application will ensure the simplicity of reporting and reporting for the elimination of irregularities, administering indirect taxes, and taxpayers. It is planned to introduce the project in the form of the state assignment with the PF «ATP». The system prototype is August, «he said. Increasing tax collection by combining a database of different sources will be implemented by the Ministry of Finance through the creation of Big Data for tax administration purposes.

$\mathrm{He}$ also noted that, based on international experience, «the implementation of modern tax administration is based on the information obtained from business for tax purposes». For example, data on the volume of transport (rail and air), as well as information on the use of water and electricity from enterprises, are compared with the income of the counterparties in the tax return. We aimed to create such a base». Overall, all digitalization measures should «significantly reduce the amount of shadow economy and increase the tax burden on the budget». Prime Minister of Kazakhstan Bakytzhan Sagintayev said that information systems should be implemented as soon as possible. "We say that information systems are not ready, and that there are many obstacles. As it runs, it gets broken quickly. It looks like there is no interference with a person. Because bureaucracy are effective. It will lead to corruption. Especially customs and tax authorities. All projects should be launched immediately», said the Prime Minister [18].

Finally, as a result of digitization of the taxation system, it is planned to collect GDP by approximately $9 \%$ by 2025 without increasing the tax burden and size.

\section{REFERENCES}

[1] S. Qulpibaeev, Vladimir Melnikov Tractatus de nulla, consequat. Almaty: LEM, 2009.

[2] AD Ümbetəlïev, Ğ.E.Kerimbek "tax vectigalibus ac". oqwlıq- Almaty: Economics, 2011.

[3] M. A. Serikova , L. M. Sembiyeva , A. O. Zhagyparova, J. Jasaitis «The tax potentialand its evaluation in innovative development of the republic of Kazakhstan». The Bulletin of the National academy of sciences of the Republic of Kazakhstan. 2018. № 4. P. 121. https://doi.org/10.32014/2018.2518-1467

[4] Shalkibayeva Zh. A., Uteyev B.Zh. «Methodical toolkit of regional tax potential assessement». Reports of the National academy of sciences of the Republic of Kazakhstan.2018.№2. P. 79. https://doi.org/10.32014/2018.2518-1483

[5] Ğ.E.Kerimbek "Nalogi et nalogooblojenïe". Russkoye T-Latina slovar. 1. Almaty, Economics, 2012.

[6] Ğ.E.Kerimbek "Nalogï et nalogooblojenïe". Russkoye T-Latina slovar. 2. Almaty, Economics, 2012.

[7] "Reipublicae Kazakhstan" De pecuniae vectigales, cetera debitum ad budget solutiones, inter huiusmodi animadversiones expanse ad tax code (CIC). January I, 2018. Astana.

[8] A. D Ümbetəliev, Ğ.E.Kerimbek "tax vectigalibus ac". C. I: doceo / culi., Terminals. 3 bas.- Almaty: Economics: 2013.

[9] Ğ.E.Kerimbek "Nalogï et nalogooblojenïe". Russkoye-Latina slovar.2 ïzdanïe. C. 1. Almaty, Economics, 2015.

[10] Ğ.E.Kerimbek "Nalogï et nalogooblojenïe". Russkoye-English dictionary. T. II ïzdanïe 2. Almaty, Economics, 2015.

[11] N.K.Kwçwkova, Ğ.E.Kerimbek "fiscal consilio". Textbook. Almaty, Economics, 2016.

[12] Umbetaliev A.D. "Taxation theory: history of development and stages of formation". Monograph. Almaty: Economics, 2017.-476 p. 
[13] Kerimbek Ğ.E. "Tax vectigalibus ac". Almaty textbook: Economics, 2016.

[14] Annual report, Ministry of Finance of the Republic of Kazakhstan, 2016.

[15] Annual report Ministry of Finance of the Republic of Kazakhstan, 2017.

[16] Report on the execution of the republican budget, Accounts committee for control over execution of the Republican Budget, 2016.

[17] Report on the execution of the republican budget, Accounts committee for control over execution of the Republican Budget, 2017.

[18] http://abctv.kz/kz/news/blokchejn-salyk-zhinauga-komektesedi.

\author{
Ғ.Керімбек ${ }^{1}$, Л.Молдашбаева ${ }^{1}$, Қ.Джрауова ${ }^{2}$, А.Ажмухамедова $^{1}$ А.Мизанова $^{1}$ \\ ${ }^{1}$ Л.Н.Гумилев ат. Евразия ұлттық университеті, Астана қ.; \\ ${ }^{2}$ Қорқыт Ата ат. Қызылорда мемлекеттік университеті, Қызылорда қ.
}

\title{
ҚАЗАҚСТАН РЕСПУБЛИКАСЫНЫН РЕСПУБЛИКАЛЫҚ БЮДЖЕТІНЕ ТУСЕТІН САЛЫҚ ТУСІМДЕРІНІҢ КӨРСЕТКІШТЕРІН ТАЛДАУ ЖӘНЕ БАҒАЛАУ
}

Аннотация. Мақалада «Салықтық әкімшіліктендіруді цифрландыру» бағыты төрт бастамадан тұрады: яғни «Электронды шот-фактуралар» және «Тауарларды таңбалау» ақпараттық жүйесі, блокчейн технология-сын қолдану арқылы ҚҚС-ны әкімшілдендіру, сонымен қатар әр түрлі дереккөздерінің мәлімет базасын біріктіру арқылы салық жинауды арттыру мәселелері қарастырылған. «Электронды шот-фактуралар» ақпа-раттық платформасы таяуда құрылғанын, «интерфейстің қолайлығы мен тауарларды алып өтуді бақылауға қатысты функционалды құруға қатысты» толықтырылуда. «Жүйені қолданушылар саны күн санап артып келеді, бүгінгі күні оның саны 158 мыңнан артық, оларға 65 млн-нан артық ЭШФ берілген». «Тауарларды таңбалау» ақпараттық жүйесі теріден жасалған өнімдерді таңбалау және ЕАЭО аясы бойынша қанат қақты жобаны қарастырады. Қорыта келгенде, салық салу жүйесін цифрландыру нәтижесінде, 2025 жылға қарай салық жүктемесі мен мөлшерін ұлғайтпай-ақ ЖІӨ-ні шамамен 9\%-ға арттыру арқылы жинауды жоспарлауға болады. фактура

Түйін сөздер: салық, бюджет, инвестиция, кіріс, шығыс, салықтық әкімшіліктендіру, кеден, электронды шот-

\author{
Ғ.Керімбек ${ }^{1}$, Л.Молдашбаева ${ }^{1}$, Қ.Джрауова ${ }^{2}$, А.Ажмухамедова $^{1}$ А. Мизанова $^{1}$ \\ ${ }^{1}$ Евраазиский национальный университет им.Л.Н.Гумилева, г. Астана; \\ ${ }^{2}$ Кызылординский государственный университет им. Коркыт Ата, г.Кызылорда
}

\section{АНАЛИЗ И ОЦЕНКА ПОКАЗАТЕЛЕЙ НАЛОГОВЫХ ПОСТУПЛЕНИЙ В РЕСПУБЛИКАНСКИЙ БЮДЖЕТ РЕСПУБЛИКИ КАЗАХСТАН}

\footnotetext{
Аннотация. Направление «цифровизация налогового администрирования» включает четыре ини-циативы: информационная система «Электронные счета-фактуры» и «Маркировка товаров», администриро-вание НДС с применением технологии блокчейн, а также увеличение сбора налогов посредством объединения базы данных из различных источников. Недавно была создана информационная платформа «Электронные счета-фактуры», дополняется относительно «удобства интерфейса и создания функцио-нальных возможностей для контроля за перемещением товаров». «Количество пользователей системы растет с каждым днем, на сегодняшний день их количество составляет более 158 тысяч, которым выдано более 65 млн ЭСФ». Информационная система «Маркировка товаров» предусматривает маркировку продукции из кожи и актуальные проекты в рамках ЕАЭС. Таким образом, в результате цифровизации системы налогообложения, к 2025 году без увеличения налоговой нагрузки и размера можно планировать увеличение сбора ВВП примерно на $9 \%$.

Ключевые слова: налоги, бюджет, инвестиции, доходы, расходы, налоговое администрирование, таможня, электронная счета-фактура.

Information about authors:

Galymzhan Yeskarauly Kerimbek - candidate of economic sciences, docent, head of the department «Finanse», Eurasian national university of L.N. Gumilyov. E-mail: kerimbek2009@mail.ru;

Moldashbayeva Luiza Polathanovna - candidate of economic sciences, Associate Professor of the Department «Accounting, audit and analysis», The Eurasian National University after L.N. Gumilev. E-mail: moldashbayeva lp@enu.kz;

Jrauova Kuralay Serikovna - candidate of economic sciences, Acting Associate Professor of the Department «Finance», The Korkyt Ata Kyzylorda State University. E-mail: 75zhkyra@,mail.ru;

Azhmukhamedova Assem Askarovna - candidate of economic sciences, Senior lecturer of the Department «Finance», The Eurasian National University after L.N. Gumilev. E-mail: azhmuxamedova@mail.ru;

Misanova Ainur Berikkyzy - master student, The Eurasian National University after L.N. Gumilev. E-mail: ainur.mizanova@mail.ru
} 


\section{МАЗМҰНЫ}

Беспаева Р.С., Бугубаева Р.О., Мануэль Ф. Грела2. Көрсеткіштердің теңдестірілген жүйесі негізінде Щучинск-Бурабай курорттық аймағын дамытудың кешенді стратегиясын қалыптастыру ................................................................................ 5

Аюпова 3.К., Құсайынов Д.Ө.Азаматтық процесстерді жетілдірудегі интеграцияның кейбір қырлары...................... 13

Құсайынова А. А., Вальдемар Козловски, Геращенко И. П.Қазақстан республикасындағы міндетті әлеуметтік сақтандырудың қаржылық-құқықтық тетіктерінің ерекшеліктері.

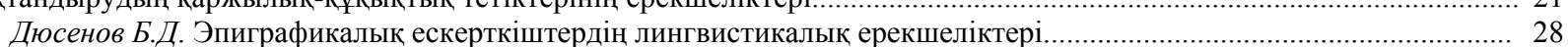

Джумадилова Ш.Г., Атабай Б.Ж. Қазақстандағы халықтың жинақтарының динамикасы......................................... 33

Карабалина А.А., Альситова А. Б., Кереймаганбетова Ж.Н., Абишева Н. М. Құндылық - рухани-адамгершілік

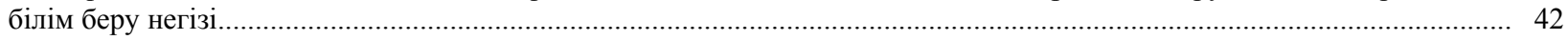

Кенжебаева Д.К., Өрмөрза Б. Ғ., Дашгин Махаммадли. Қазақстандық заманауи жастардың құндылығы............. 51

Нурманова А.Ш., Медерова Д.Е., Дюсенов Б.Д. «Бөкейхан әулетінің талдыбейіт қорымы» эпиграфикалық ескерткіштері тарихи дереккөз ретінде.

Кыдырова Ж.Ш., Онласынов Е.З., Абишова А.У., Шадиева А.А. Оңтүстік Қазақстан облысы сүт және сүт өнімдері нарығындағы жағдайды зерттеу ......

Абимова Г.У., Аманжолов Р., Мынбаева Б.Н., Ибрагимова Д.И. ЖОО-да биолог-студенттердің жобаларды

ұйымдастырылуы мен орындалуына даярлығы.......

Балтабаева А.Ю., Ризаходжаева Г. Мәдени интеграция үдерісіндегі жібек жолының феномені............................... 9

Бурганова Р.И., Абдугалина С.Е., Туякова А.Е. Студенттерге бағытталған білім беру арқылы білім сапасын

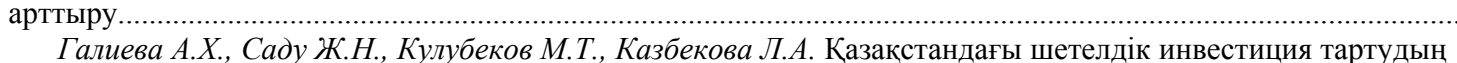

институционалдық жағдайын (талаптарын) бағалау..

Джалилов 3.Г., Батырхан Б.Ш. ХX ғ. екінші жартысындағы шетелдік исламтанушылардың ислам және саясат

туралы теориялық дискурсы.......

Джумабекова А.Т., Канатова А.Ж. Қаржылық ынтымақтастық жағдайларындағы Қазақстан республикасының

ұлттық банкінің өткізу механизмінің өзгеруі......

Дүйсен Г. М., Айтжанова Д. А. Қазақстан және Орталық Азия елдеріндегі көші-қон процесстері дамуының мәселелері мен ерекшеліктері

Есендұлова М.Н. Қазақстандағы « Қиын балаларды» оңалтудың және әлеуметтендірудің психологиялық ерекшеліктері

Жакишева К.М., Жуманова Д.Т., Мукашева Г.М. Экономиканың аграрлық секторының тұрақты дамуына арналған ауыл шаруашылық кәсіпорындарының қаржылық шарттарын мониторингінің рөлі.....

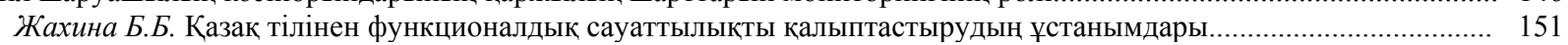

Идресова У.Х., Садуахасова 3.Ж., Муханова А.Т. Криминалистика....................................................................... 156

Савельева В. В. Қазақстандағы кредит технологиясын пайдалану және дамуының тарихи және педагогикалық базасы.

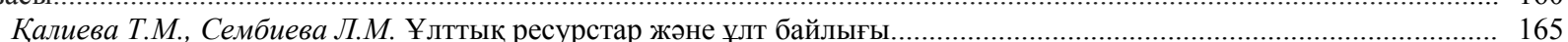

Каримова Р.У., Хаджиева Г.У. ҚХР Ұлттық саясаты контексіндегі ШҰАА-ның этносаяси және әлеуметтікэкономикалық трансформациясы мәселесі.

Керімбек Г., Молдашбаева Л., Джрауова Қ., Ажмухамедова А., Мизанова А. Қазақстан республикасының

республикалық бюджетіне түсетін салық түсімдерінің көрсеткіштерін талдау және бағалау.....

Жолдасбекова С.А., Парманкулова П.Ж., Асаналиев М.К. Мүмкіндігі шектеулі балаларды дамытудағы ұлттық ойындар

Молдакенова Е.К., Байгабулова К.К., Онаева Б.Т. БҚО-да инновациялық үрдістерді басқарудың аймақтық

аспектілігі жүйесінің дамудың жолдары.

Мұратова Г.К., Шаушенова А.Г., Жумасеитова С.Д., Онұварбаева М.Б.Білім беру үрдісінде бұлттық

технологияларын қолдану......

Несіпбеков E. Н., Аппакова Г.Н. Кәсіпорынның инвестициялық портфелін қалыптастырудың теориялық

Нургабылов М.Н., Барлыков Е.К., Егембердиева С.М. ҚР есеп өнеркәсібінің дамуының басқаруының трендсі....... 220

Нурымбетов Т.Я., Абишова А.У., Уразбаева Г.Ж., Кыдырова Ж.Ш., Байнеева П.Т., Абишо Н.У. Модернизациялық

жағдайындағы қр халқын әлеуметтік қолдауының басымдықтары.....

Рахимова С. А., Тургумбекова М. М. Қазақстан республикасындағы шағын және орта бизнестіңмемлекеттік қолдау

бағдарламалары және олардың тиімділігін жүзеге асыру шаралары.......................................................................... 233

Руденко Е.И. Орталық пен Оңтүстік Азия мемлекеттері арасындағы ұғынудың бұрмалануы - «Жұмсақ күш»

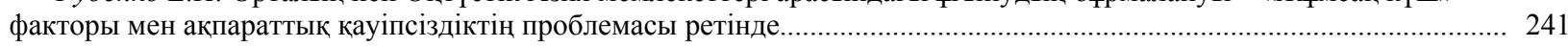

Тохтабаева Ш. Қазына-сандық.......................................................................................................... 251

Утепкалиева К.М., Сабирова Р.К., Кенбаева Г.У. Мұнай-газ секторындағы мемлекеттік-жеке серіктестікті дамыту

Мыңбаев Д. Е. Банкте басқару есебін ұйымдастыру тұжырымдамасы...

Султанова Г.С. Жаңа формацияның экономисі - бакалаврдың кәсіби құзыреттілігін қалыптастырудың

Шаяхметова А.А. Университет жағдайында инклюзивті білім беру үшін педагогтарды оқыту....... 


\section{СОДЕРЖАНИЕ}

Беспаева Р.С., Бугубаев Р.О., Мануэль Ф. Грела. Формирование комплексной стратегии развития ЩучинскоБоровской курортной зоны на основе сбалансированной системы показателей. Аюпова 3.К., Кусаинов Д.У., Уинстон Наган. Некоторые грани интеграции в совершенствовании гражданского процесса.

Кусаинова А.А., Козловски Вальдемар, Геращенко И.П. Обзор некоторых особенностей финансово-правового механизма обязательного социального страхования в республике Казахстан......

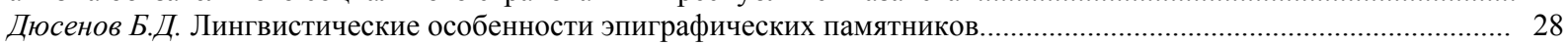

Джумадилова Ш.Г., Атабай Б.Ж.Динамика сбережений населения в Казахстане................................................... 33

Карабалина А.А., Альситова А. Б., Кереймаганбетова Ж.Н., Абишева Н. М. Ценность как базовая основа духовнонравственного образования.

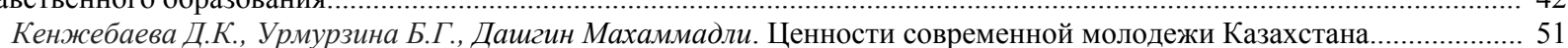

Нурманова А.Ш., Медерова Д.Е., Дюсенов Б.Д. Эпиграфические памятники «Некрополи талдыбейит династии

Бокейхановых» как исторический источник.

Кыдырова Ж.Ш., Онласынов Е.З., Абишова А.У., Шадиева А.А.Исследование ситуации на рынке молока и молочной продукции южно-казахстанской области

Абишова Г.У., Аманжолов Р., Мынбаева Б.Н., Ибрагимова Д.И. Готовность студентов-биологов к организации

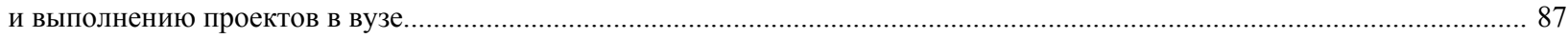

Балтабаева А.Ю., Ризаходжаева Г. Феномен великого шелкового пути в процессе культурной интеграции............... 91

Бурганова Р.И., Абдугалина С.Е., Туякова А.Е. Повышение качества образования посредством

студентоцентрированного обучения...

Галиева А.Х., Саду Ж.Н., Кулубеков М.Т., Казбекова Л.А. Оценка институциональных условий привлечения

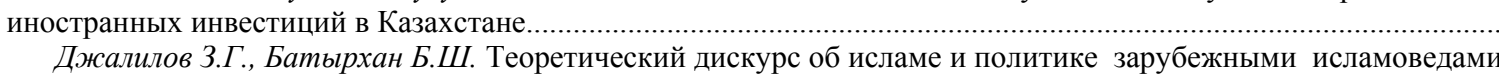
второй половины ХX в.

Джумабекова А.Т., Канатова А.Ж. Трансформация трансмиссионного механизма национального банка республики

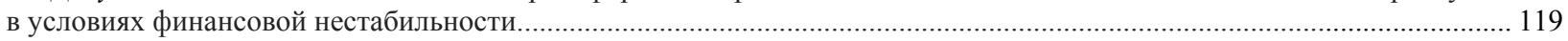

Дуйсен Г.М., Айтжанова Д.А. Проблемы и особенности развития миграционных процессов в Казахстане

и странах Центральной Азии.

Есенгулова М.Н. Психологические особенности реабилитации и социализации "Трудных подростков"

в Казахстане".

Жакишева К.М., Жуманова Д.Т., Мукашева Г.М.Роль мониторинга финансового состояния сельскохозяйственных

предприятий в обеспечении устойчивого развития аграрного сектора экономики.........................................................146

Жахина Б.Б. Принципы формирования функциональной грамотности казахского языка.......................................... 151

Идресова У.Х., Садуахасова 3.Ж., Муханова А.Т. Криминалистика......................................................................... 156

Савельева B.B. Исторические и педагогические основы формирования и разработки кредитной технологии

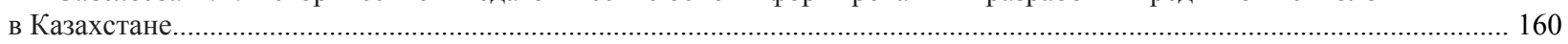

Калиева Т.М., Сембиева Л.М. Национальные ресурсы и богатство нации.................................................. 165

Каримова Р.У., Хаджиева Г.У. К вопросу об этно-политической и социально-экономической трансформации

СУАР в контексте национальной политики КНР

Керимбек Г., Молдашбаева Л., Джрауова Қ., Ажмухамедова А., Мизанова А. Анализ и оценка показателей

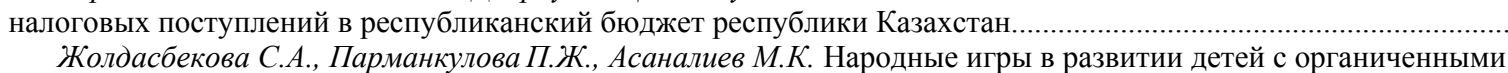

Жолдасбекова С.А., Парманкулова П.Ж., Асаналиев М.К. Народные игры в развитии детей с органиченными

Молдакенова Е.К., Байгабулова К.К., Онаева Б.Т.Пути развития системы регионального аспекта управления

инновационными процессами в АПК.

Муратова Г.К., Шаушенова А.Г., Жумасеитова С.Д., Онгарбаева М.Б. Применение облачных технологий

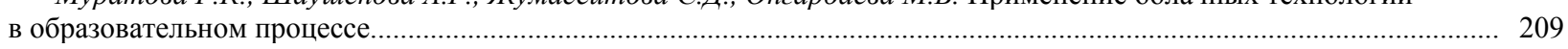

Несипбеков Е.Н., Аппакова Г.Н. Теоретические аспекты формирования инвестиционного портфеля предприятия. 214

Нургабылов М.Н., Барлыков Е.К., Егембердиева С.M. Тенденции управления развитием мясоперерабаты-

вающей отрасли в РК.

Нурымбетов Т.Я., Абишова А.У., Уразбаева Г.Ж., Кыдырова Ж.Ш., Байнеева П.Т., Абишов Н.У. Приоритеты

социальной поддержки населения РК в условиях модернизации................................................................................. 22

Рахимова С. А., Тургумбекова М. М. Программы государственной поддержки мсб в республике Казахстан и меры

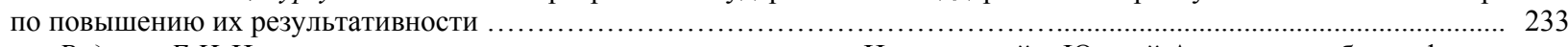

Руденко Е.И. Искаженность восприятия между государствами Центральной и Южной Азии как проблема фактора

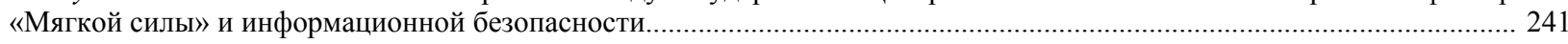

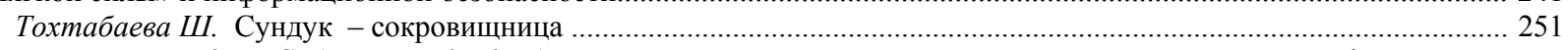

Утепкалиева К.М., Сабирова Р.К., Кенбаева Г.У.Развитие государственно-частного партнерства в нефтегазовой

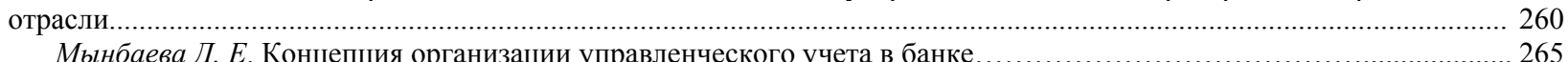

Мынбаева Д. Е. Концепция организации управленческого учета в банке...........................................2.
Султанова Г.С. Педагогические аспекты формирования профессиональных компетенций бакалавра - экономиста

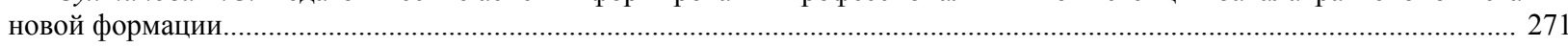

Шаяхметова А.А. О подготовке педагогических кадров к инклюзивному образованию в условиях вуза................ 277 


\section{CONTENTS}

Bespayeva R.S., Bugubayeva R.O., Manuel F. Grela. Formation of the complex strategy for development of the Schuchinsk-

Burabay resort area based on the balanced system of indicators.

Ayupova Z.K., Kussainov D.U., Winston Nagan. Some facets of integration in themodernization ofthe civil process..............13

Kussainova A.A., Kozlowski Waldemar, Gerashchenko I.P. The review of some features of the financial legal mechanism of obligatory social insurance in the republic of Kazakhstan...

Dyussenov B.D. Linguistic features of epigraphic monuments................................................................................ 28

Jumadilova Sh.G., Atabay B.Zh. Dynamics of the population savings in Kazakhstan.......................................................... 33

Karabalina A.A., Alsitova A.B., Kereimaganbetova Zh.N., Abisheva N.M. The values as critical factor of moral education... 42

Kenzhebayeva D.K., Urmurzina B.G., Dashqin Mahammadli. The modern youth values in Kazakhstan............................. 51

Nurmanova A.S., Mederova D.E., Dyussenov B.D. "Bokeykhanov dynasty taldybeyit necropolis" epigraphic monuments

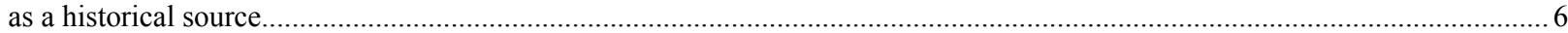

Kydyrova Zh.Sh., Onlasynov E.Z., Abishova A.U., Shadieva A.A.Research of the situation in the market of milk and dairy

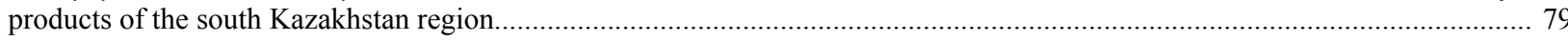

Abishova G.U., Amanzholov R.A., Mynbayeva B.N., Ibragimova D.I. Readiness of students-biologists for the organization

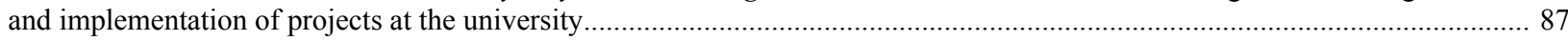

Baltabayeva A.Y., Rizakhojayeva $G$. The phenomenon of the great silk road in the cultural integration process................... 91

Burganova R.I., Abdugalina S.E., Tuyakova A.E. Improving the quality of education through student-centered education... 102

Galiyeva A.Kh., Sadu Zh.N., Kulubekov M.T., Kazbekova L.A. Assessment of the institutional terms of the foreign

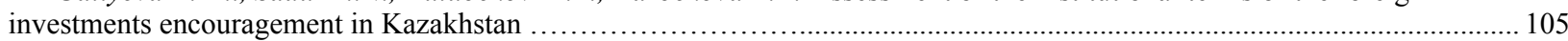

Dzhalilov Z.G. Theoretical discourse on islam and politics in foreign humanism of the second half of 20th century.......... 112

Dzhumabekova A.T., Kanatova A.ZH. Transformation of the transmission mechanism of the national bank of the republic

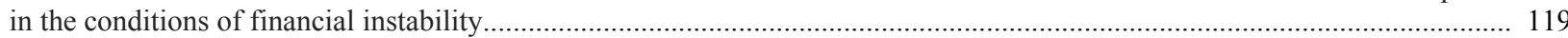

Suleimenov R.B. Problems and features of the development of migration processes in Kazakhstan and Central Asia.......... 124

Yesengulova M.N. Psychological aspects of reintegration and resocialization of "Trouble" adolescents in Kazakhstan....... 134

Zhakisheva K.M., Zhumanova D.T., Mukasheva G.M.The role of monitoring the financial condition of agricultural

enterprises in ensuring sustainable development of the agrarian sector of the economy......................................................... 146

Zhakhina B.B. Principles of functional literacy formation of the kazakh language....................................................... 151

Idresova U.Kh., Saduahasova Z.Zh., Mukhanova A.T. Criminalistics............................................................................. 156

Savelyeva $V . V$. Historicalandpedagogical bases of formation and development of credit technology in Kazakhstan........... 160

Kaliyeva T.M., Sembiyeva L.M. National Resources and national wealth.................................................................. 165

Karimova R., Hajiyeva G. Examining ethno-political and SOCIO-economic transformation of the xinjiang uyghur

autonomous region in the context of the PRC national policies........................................................................................ 176

Kerimbek G., Moldashbayeva L., Jrauova K., Azhmukhamedova A., Misanova A. Analysis and evaluation of reduction

of tax recovery of the republic of kazakhstan on the budget of the republic of Kazakhstan................................................. 185

Zholdasbekova S.A., Parmankulova P.Zh., Assanaliyev M.K. Folk games in the education of children with physical, mental and sensory disturbances..

Moldakenova E.K., Baygabulova K.K., Onaeva B.T. Ways of development of the system of the regional aspect of managing innovative processes in the APC.

Muratova G.K., Shaushenova A.G., Zhumassseitova C.D., Ongarbayeva M.B. Application of cloud technologies in the educational process......

Nurgabylov M.N., Barlikov E.K., Egemberdieva S.M. Trends of management of the development of meat processing industry in RK

Nurymbetov T.Ya., Abishova A.U., Urazbaeva G.Zh., Kydyrova Z.Sh., Baineeva P.T., Abishov N.U. Priorities of social support of the population of republic of Kazakhstan in the conditions of modernization........

Rakhimova S. A., Turgumbekova M. M. Programs of government support for sme in the republic of Kazakhstan and measures to enhance their efficiency.....

Rudenko Ye.I. Misperception between the states of Central and South Asia as a 'Soft power' and information security issue...

Tokhtabayeva Sh. Zh. Treasure-chest.

Utepkalieva K.M., Sabirova R.K., Kenbaeva G.U.Development of public private partnership approach in oil and gas

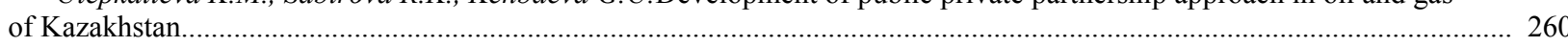

Mynbayeva D.E. Concept of organization of management accounting in bank ........................................................... 265

Sultanova G. S. Pedagogical aspects of formation of professional competence of the bachelor-economist of the new formation

Shayakhmetova A.A. On the training of teaching staff for inclusive education under the conditions of higher education institution. 


\section{PUBLICATION ETHICS AND PUBLICATION MALPRACTICE IN THE JOURNALS OF THE NATIONAL ACADEMY OF SCIENCES OF THE REPUBLIC OF KAZAKHSTAN}

For information on Ethics in publishing and Ethical guidelines for journal publication see http://www.elsevier.com/publishingethics and http://www.elsevier.com/journal-authors/ethics.

Submission of an article to the National Academy of Sciences of the Republic of Kazakhstan implies that the work described has not been published previously (except in the form of an abstract or as part of a published lecture or academic thesis or as an electronic preprint, see $\mathrm{http} / / / \mathrm{www} . e l s e v i e r . c o m / p o s t i n g p o l i c y)$, that it is not under consideration for publication elsewhere, that its publication is approved by all authors and tacitly or explicitly by the responsible authorities where the work was carried out, and that, if accepted, it will not be published elsewhere in the same form, in English or in any other language, including electronically without the written consent of the copyrightholder. In particular, translations into English of papers already published in another language are not accepted.

No other forms of scientific misconduct are allowed, such as plagiarism, falsification, fraudulent data, incorrect interpretation of other works, incorrect citations, etc. The National Academy of Sciences of the Republic of Kazakhstan follows the Code of Conduct of the Committee on Publication Ethics (COPE), and follows the COPE Flowcharts for Resolving Cases of Suspected Misconduct (http://publicationethics.org/files/u2/New_Code.pdf). To verify originality, your article may be checked by the originality detection service Cross Check http://www.elsevier.com/editors/plagdetect.

The authors are obliged to participate in peer review process and be ready to provide corrections, clarifications, retractions and apologies when needed. All authors of a paper should have significantly contributed to the research.

The reviewers should provide objective judgments and should point out relevant published works which are not yet cited. Reviewed articles should be treated confidentially. The reviewers will be chosen in such a way that there is no conflict of interests with respect to the research, the authors and/or the research funders.

The editors have complete responsibility and authority to reject or accept a paper, and they will only accept a paper when reasonably certain. They will preserve anonymity of reviewers and promote publication of corrections, clarifications, retractions and apologies when needed. The acceptance of a paper automatically implies the copyright transfer to the National Academy of sciences of the Republic of Kazakhstan.

The Editorial Board of the National Academy of sciences of the Republic of Kazakhstan will monitor and safeguard publishing ethics. 
Правила оформления статьи для публикации в журнале смотреть на сайте:

\section{www:nauka-nanrk.kz}

\section{social-human.kz}

Редакторы М.С. Ахметова, Т.А. Апендиев, Д.С. Аленов

Верстка на компьютере А.М. Кульгинбаевой

Подписано в печать 08.12.2018

Формат 60x881/8. Бумага офсетная. Печать - ризограф.

17,7 п.л. Тираж 500. Заказ 6.

Национальная академия наук $Р К$

050010, Алматы, ул. Шевченко, 28, т. 272-13-18, 272-13-19 